\title{
PENGARUH PENERAPAN METODE ROLE PLAY DAN GAYA BELAJAR TERHADAP KETERAMPILAN KONSELING MAHASISWA TENTANG ADAPTASI PSIKOLOGI PADA KEHAMILAN TRIMESTER I (Studi Eksperimental di Prodi DIII Kebidanan Universitas Sebelas Maret Surakarta)
}

\author{
Luluk Khusnul Dwihestie, Bhisma Murti, dan Nunuk Suryani \\ Universitas Sebelas Maret Surakarta \\ Email: Lulu.khusnul64@yahoo.com
}

\begin{abstract}
Abstrak
Penelitian ini bertujuan untuk menganalisis pengaruh penerapan metode role play dan gaya belajar terhadap keterampilan konseling mahasiswa tentang adaptasi psikologi pada kehamilan trimester I. Desain penelitian yaitu studi eksperimental dengan Randomized Controlled Trial (RCT). Subjek penelitian adalah seluruh mahasiswa semester II Prodi DIII Kebidanan Fakultas Kedokteran Universitas Sebelas Maret Surakarta tahun ajaran 2013/2014, sebanyak 45 mahasiswa. Pengambilan sampel menggunakan exhaustive sampling dengan kriteria inklusi dan eksklusi. Instrumen penelitian yaitu kuesioner dan checklist. Analisis data menggunakan uji regresi linier ganda dengan taraf signifikan 0.05. Hasil analisis regresi linier ganda, metode role play dan gaya belajar secara bersamaan mampu menjelaskan 28\% dari variasi keterampilan konseling, sedangkan sisanya dijelaskan oleh variabel yang tidak diteliti. Berdasarkan kesimpulan hasil penelitian membuktikan bahwa keterampilan konseling mahasiswa dapat ditingkatkan dengan penerapan metode role play dan identifikasi gaya belajar pada setiap mahasiswa
\end{abstract}

Kata kunci: Role Play, Gaya Belajar, Keterampilan Konseling

\section{THE EFFECT OF ROLE PLAY METHOD AND LEARNING STYLE TO STUDENTS' COUNSELING SKILLS ON PSYCHOLOGICAL ADAPTATION IN PREGNANCY TRIMESTER I (Experimental Studies in D III Midwivery, UNS)}

\begin{abstract}
This research aim to analyze the influence of role play method and learning style to students' counseling skill on psychologycal adaption in pregnancy trimester I. The study used experimental with Randomized a Controlled Trial (RCT). The sampling methods used exhaustive sampling with inclusion and exclusion criteria (n-45 students). The instrument used questionnaire and checklist. Data were analysed by using test multiple linier regression with significancy 0.05 . The result showed there was a positive influence and statistically significant increase on applying the method of role play for counseling skill $(b=6.86$, CI 95\%=64.35-92.31, $\mathrm{p}=0.009)$. There is a positive influence but not statistically significant increase visual learning style for counseling skill $(b=0.13, \mathrm{CI}$ $95 \%=0.85-1.12, p=0.783$ ). There is a negative influence and statistically significant at the auditorial learning style for counseling skill $(b=-0.97$, CI $95 \%=(-1.80-(-0.14), p=0.023)$. There is a positive influence and statistically significant at kinesthetic learning style for counseling skill $(b=1.28$, CI $95 \%=0.42-2.15, p=0.005)$. The results of multiple linear regression analysis is that role play and learning style simultaneously are able to explain $28 \%$ of the variation of counseling skill, the remaining described by not examined variables. Result proves that students' counseling skill can be increased by using role play and identifying learning style of the students.
\end{abstract}

Keywords: Role Play, Learning Style, Counseling Skill 


\section{PENDAHULUAN}

Pendidikan merupakan faktor penting dalam menentukan kualitas kehidupan bangsa. Menurut UU No. 20 tahun 2003 tentang Sistem Pendidikan Nasional, pendidikan adalah usaha sadar dan terencana untuk mewujudkan suasana belajar dan proses pembelajaran agar peserta didik secara aktif mengembangkan potensi dirinya untuk memiliki kekuatan spiritual keagamaan, pengendalian diri, kepribadian, kecerdasan, akhlak mulia, serta keterampilan yang diperlukan dirinya, masyarakat, bangsa dan negara.

Wujud implementasi pendidikan salah satunya adalah proses belajar mengajar. Keberhasilan proses belajar mengajar sangat dipengaruhi oleh metode pembelajaran. Pendidik harus dapat mengetahui metode pembelajaran yang sesuai dengan bahan ajar. Yamin (2008:75) menyatakan metode pembelajaran merupakan bagian dari strategi instruksional yang berfungsi sebagai cara untuk menyajikan, menguraikan, memberi contoh, dan memberi latihan kepada peserta didik untuk mencapai tujuan tertentu.

Metode pembelajaran yang efektif dan interaktif akan berdampak positif terhadap pencapaian tujuan pembelajaran. Variasi pemilihan metode pembelajaran dilakukan untuk meningkatkan pencapaian hasil belajar peserta didik. Salah satu metode pembelajaran yang memerlukan keaktifan peserta didik yaitu role play. Metode role play adalah suatu aktifitas pembelajaran terencana yang dirancang untuk mencapai tujuan-tujuan pendidikan yang spesifik. Role play dapat dipandang sebagai suatu metode yang sesuai pada banyak materi, di mana terdapat peran-peran yang dapat didefinisikan dengan jelas, memiliki interaksi yang mungkin dieksplorasi dalam keadaan yang bersifat simulasi atau skenario (Zaini, Munthe, dan Aryani, 2007:34).
Prosedur penerapan metode role play menurut Uno (2010:32) yaitu sebagai berikut:

1) Pemanasan (warming up), di mana pendidik berupaya untuk mengenalkan peserta didik pada permasalahan sebagai suatu hal yang bagi semua orang perlu mempelajari dan menguasainya.

2) Pemilihan partisipan dan membahas karakter dari setiap tokoh yang diperankan.

3) Menata panggung, dalam hal ini pendidik mendiskusikan terlebih dahulu dengan peserta didik dimana dan bagaimana peran itu akan dimainkan. Apa saja kebutuhan yang diperlukan. Penataan panggung ini dapat sederhana atau kompleks.

4) Menyiapkan pengamat, dalam kegiatan ini pengamat juga harus terlibat aktif dalam permainan peran.

5) Memainkan peran, permainan peran dilaksanakan secara spontan.

6) Diskusi dan evaluasi, pendidik bersama peserta didik

7) mendiskusikan permainan yang telah dilaksanakan dan melakukan evaluasi terhadap tokoh-tokoh yang diperankan.

8) Berbagi pengalaman dan kesimpulan, peserta didik diajak untuk berbagi pengalaman tentang tema permainan yang dilakukan dan dilanjutkan dengan membuat kesimpulan.

Manfaat dari penerapan metode pembelajaran role play di perguruan tinggi yaitu (1) Dapat mendemonstrasikan pengetahuan, keterampilan, dan kemampuan, (2) Merupakan integrasi pengetahuan praktis, (3) Dapat menerapkan pengetahuan pada pemecahan masalah, (4) Menjadikan masalah yang abstrak menjadi konkrit, (5) Mendorong peserta didik untuk mengembangkan pengetahuan dalam cara yang dinamik, (6) Memfasilitasi ekspresi sikap dan perasaan peserta didik, dan (7) Mengembangkan 
pemahaman yang empatik (Zaini, Munthe, dan Aryani, 2007:21).

Metode pembelajaran yang sering digunakan para pendidik dalam proses belajar mengajar yaitu metode ceramah. Menurut Majid (2013:12) metode ceramah adalah metode pembelajaran yang menggunakan cara penuturan (lisan) dalam mengembangkan proses pembelajaran.

Menurut Zaini, Munthe, dan Aryani, (2007:60) langkah-langkah penggunaan metode ceramah yaitu:

a. Tahap persiapan, artinya tahap dimana pendidik menciptakan kondisi belajar yang baik dan kondusif sebelum pembelajaran dimulai.

b. Tahap penyajian, yaitu tahap pendidik menyampaikan materi pembelajaran.

c. Tahap komparasi, pada tahap ini pendidik memberikan kesempatan kepada peserta didik untuk menanyakan hal-hal yang masih kurang dimengerti, dapat pula terjadi diskusi.

d. Tahap generalisasi atau kesimpulan, yaitu pendidik bersama dengan peserta didik menyimpulkan materi yang telah dipelajari.

e. Tahap evaluasi, tahap ini diadakan penilaian terhadap peserta didik mengenai pemahaman materi. Evaluasi dapat dalam bentuk lisan maupun tertulis atau tugas.

Ada beberapa kelebihan penggunaan metode ceramah menurut Majid (2013:52) sehingga sampai saat ini metode ceramah masih sering digunakan oleh pendidik, yaitu:

a. Ceramah merupakan metode yang murah dan mudah untuk dilakukan.

b. Ceramah dapat menyajikan materi pembelajaran yang luas.

c. Dapat memberikan pokok-pokok materi yang perlu ditonjolkan atau

d. ditekankan sesuai dengan kebutuhan dan tujuan yang ingin dicapai.

e. Melalui ceramah pendidik dapat mengontrol kondisi kelas.

Keberhasilan proses belajar mengajar tidak hanya ditentukan dari pemilihan metode pembelajaran yang sesuai bahan ajar, tetapi juga dipengaruhi oleh faktor internal yang berasal dari dalam diri peserta didik. Uno (2010:32) menyatakan bahwa kemampuan peserta didik untuk memahami dan menyerap materi pembelajaran yang disampaikan sudah pasti berbeda antara yang satu dengan yang lain. Ada yang cepat, sedang, dan ada pula yang sangat lambat sehingga peserta didik seringkali menempuh cara yang berbeda untuk menerima informasi atau materi yang sama.

Cara yang ditempuh peserta didik dalam menerima materi pembelajaran sering disebut dengan gaya belajar. Nasution (2003:12) menyatakan bahwa gaya belajar adalah cara yang relatif tetap dan konsisten dilakukan seorang pebelajar dalam menangkap stimulus atau informasi, cara mengingat, berfikir, dan memecahkan masalah.

Menurut Bandler dan Grinder (DePorter \& Hernacki, 2013:43), kebanyakan peserta didik memiliki kecenderungan untuk mengakses kepada tiga tipe gaya belajar, yaitu

1) Gaya Belajar Visual

Peserta didik dengan gaya belajar visual memiliki ciri-ciri sebagai berikut:

a) Rapi, teratur, memperhatikan segala sesuatu, dan lebih mementingkan penampilan.

b) Berbicara dengan cepat.

c) Mengingat apa yang dilihat daripada yang didengar. Mengingat dengan gambar, lebih suka membaca daripada dibacakan.

d) Membutuhkan gambaran dan tujuan menyeluruh, serta dapat menangkap informasi secara detail.

e) Seringkali mengetahui apa yang harus dikatakan, tetapi tidak pandai memilih kata-kata.

2) Gaya Belajar Auditorial

Seorang peserta didik dengan gaya belajar auditorial bercirikan sebagai berikut: 
a) Perhatiannya mudah terpecah, mudah terganggu oleh keributan.

b) Berbicara dengan irama yang terpola.

c) Belajar dengan cara mendengarkan, menggerakkan bibir atau bersuara saat membaca.

d) Merasa kesulitan untuk menulis, tetapi hebat dalam bercerita. Biasanya pembicara yang fasih.

3) Gaya Belajar Kinestetik

Peserta didik dengan gaya belajar kinestetik memiliki ciri-ciri sebagai berikut:

a) Menanggapi perhatian fisik, selalu berorientasi pada fisik dan banyak gerak.

b) Berbicara dengan perlahan.

c) Belajar melalui manipulasi dan praktik, menghafal dengan cara berjalan dan melihat, serta menggunakan jari-jari sebagai petunjuk ketika membaca.

d) Kemungkinan tulisannya jelek, ingin melakukan segala sesuatu dan menyukai permainan yang menyibukkan.

Hasil penelitian yang telah dilakukan oleh Sarwoko (2009:42) menunjukkan bahwa metode pembelajaran role play mampu meningkatkan hasil ujian pengetahuan dan keterampilan asuhan kebidanan I bahasan pemeriksaan obstetrik setelah mengontrol pengaruh motivasi belajar.

Pada penelitian ini, peneliti menggunakan gaya belajar visual, auditorial, dan kinestetik yang diasumsikan berhubungan dengan metode pembelajaran, dalam hal ini peneliti memilih metode role play untuk meningkatkan pencapaian tujuan pembelajaran, yaitu keterampilan konseling mahasiswa tentang adaptasi psikologi pada kehamilan trimester I.

Menurut Ivey (Sofyan, 2007:10) bahwa keterampilan konseling dapat dipandang sebagai keterampilan minimal yang harus dikuasai seorang konselor profesional. Penguasaan keterampilan ini dapat sedikit banyak menjamin keberlangsungan suatu proses konseling untuk mencapai tujuan konseling. Harapan dari proses konseling yaitu konseli dapat memecahkan masalahnya sendiri demi perkembangan optimal diri konseli sendiri.

Pemberian asuhan kebidanan yang berkualitas sangat dibutuhkan dalam praktik kebidanan. Upaya peningkatan kualitas pelayanan kebidanan salah satunya ditentukan oleh keterampilan bidan dalam berkomunikasi secara efektif dan melakukan konseling yang baik kepada klien. Konseling kebidanan adalah suatu proses pembelajaran, pembinaan hubungan baik, pemberian bantuan, dan bentuk kerjasama yang dilakukan secara profesional (sesuai dengan bidangnya) oleh bidan kepada klien untuk memecahkan masalah, mengatasi hambatan perkembangan, dan memenuhi kebutuhan klien (Yulifah dan Yuswanto, 2009:23).

Menurut Jannah (2012:11) dan Sulistyawati (2009:44) perubahan psikologi trimester I (periode penyesuaian) yaitu: setelah konsepsi, kadar hormon progesteron dan estrogen dalam tubuh akan meningkat, ini menyebabkan timbulnya mual muntah, lemah, lelah, dan pembesaran payudara. Akibatnya ibu merasa tidak sehat dan seringkali membenci kehamilannya. Pada trimester I banyak ibu yang merasakan kekecewaan, penolakan, kecemasan, dan kesedihan, bahkan terkadang ibu berharap agar dirinya tidak hamil saja.

Pada masa kehamilan trimester I seorang ibu akan mencari tanda-tanda untuk meyakinkan bahwa dirinya benarbenar hamil. Setiap perubahan yang terjadi pada tubuhnya akan selalu diperhatikan dengan seksama. Hasrat untuk melakukan hubungan seks pada wanita trimester I berbeda-beda, tetapi biasanya banyak mengalami penurunan. Libido sangat dipengaruhi oleh kelelahan, rasa mual, pembesaran payudara, dan kekhawatiran. Sebagian besar wanita merasa butuh untuk dicintai dan merasakan kuat untuk mencintai namun 
tanpa berhubungan seks. Oleh karena perutnya masih kecil, kehamilan merupakan rahasia seorang ibu yang mungkin akan diberitahukannya kepada orang lain atau mungkin justru dirahasiakannya.

Tujuan penelitian ini yaitu menganalisis pengaruh penerapan metode role play dan gaya belajar terhadap keterampilan konseling mahasiswa tentang adaptasi psikologi pada kehamilan trimester I.

\section{Hipotesis Penelitian}

1. Mahasiswa dengan penerapan metode pembelajaran role play rata-rata memiliki keterampilan konseling lebih baik dibandingkan mahasiswa dengan penerapan metode pembelajaran konvensional.

2. Mahasiswa yang mempunyai gaya belajar kinestetik rata-rata memiliki keterampilan konseling lebih baik dibandingkan mahasiswa dengan gaya belajar visual atau auditorial.

3. Ada pengaruh penerapan metode role play dan gaya belajar terhadap keterampilan konseling mahasiswa tentang adaptasi psikologi pada kehamilan trimester I.

\section{METODE}

Penelitian ini dilaksanakan pada bulan Februari 2014. Desain penelitian yaitu studi eksperimental dengan menggunakan Randomized Controlled Trial (RCT). Populasi sumber adalah seluruh mahasiswa semester II Prodi DIII Kebidanan Fakultas Kedokteran Universitas Sebelas Maret Surakarta tahun ajaran 2013/2014. Pengambilan sampel dilakukan dengan teknik exhaustive sampling. diterapkan kriteria retriksi yaitu inklusi dan eksklusi.

a. Kriteria inklusi, yaitu:

1) Terdaftar sebagai mahasiswa Prodi DIII Kebidanan Universitas Sebelas Maret Surakarta tahun ajaran 2013/2014.
2) Bersedia menjadi subjek penelitian dengan menandatangani informed consent.

b. Kriteria eksklusi, yaitu: mahasiswa yang tidak hadir saat penelitian.

Variabel independen dalam penelitian ini yaitu metode role play dan gaya belajar, sedangkan variabel dependen adalah keterampilan konseling.

Untuk perlakuan proses pembelajaran, diterapkan metode role play (kelas eksperimen) diberi skor 1 dan metode ceramah (kelas kontrol) diberi skor 0. Gaya belajar diukur dengan kuesioner, terdiri dari gaya belajar visual, kinestetik, dengan skala data kontinyu. Keterampilan konseling diukur dengan checklist, skala data kontinyu. Analisis data menggunakan regresi linier ganda.

\section{HASIL DAN PEMBAHASAN Deskripsi Data Penelitian}

Tabel 1 Karakteristik Sampel Responden

\begin{tabular}{lcccc}
\multicolumn{1}{c}{$(\mathrm{n}=42)$} & & & \\
\hline \multicolumn{1}{c}{ Variabel } & Mean & SD & Min. & Maks \\
\hline Metode role play & - & - & 0 & 1 \\
Gaya belajar & & & & \\
- Visual & 13.95 & 3.29 & 3 & 22 \\
- Auditorial & 14.86 & 4.16 & 4 & 22 \\
- Kinestetik & 13.74 & 3.30 & 5 & 22 \\
Keterampilan & 86.98 & 9.44 & 60 & 100 \\
konseling & & & & \\
\hline
\end{tabular}

Sumber : Data Primer Februari 2014

\section{Pengujian Hipotesis}

Tabel 2 Hasil analisis regresi linier ganda tentang pengaruh metode role play dan gaya belajar terhadap keterampilan konseling.

\begin{tabular}{|c|c|c|c|c|c|}
\hline \multirow[b]{2}{*}{ Variabel } & \multirow[b]{2}{*}{$\begin{array}{l}\text { Koefisien } \\
\text { Regresi } \\
\text { (b) }\end{array}$} & \multirow[b]{2}{*}{$\mathrm{t}$} & \multicolumn{2}{|c|}{$\begin{array}{c}\text { Confidence } \\
\text { interval } 95 \%\end{array}$} & \multirow[b]{2}{*}{ Nilai $p$} \\
\hline & & & $\begin{array}{l}\text { Batas } \\
\text { Bawah }\end{array}$ & $\begin{array}{c}\text { Batas } \\
\text { Atas }\end{array}$ & \\
\hline Konstanta & 78.33 & 11.36 & 64.35 & 92.31 & $\begin{array}{c}< \\
0.001\end{array}$ \\
\hline $\begin{array}{l}\text { Metode Role } \\
\text { Play }\end{array}$ & 6.86 & 2.74 & 1.80 & 11.93 & 0.009 \\
\hline $\begin{array}{l}\text { Gaya Belajar } \\
\text { - Visual } \\
\text { - Auditorial } \\
\text { - Kinestetik }\end{array}$ & $\begin{array}{c}0.13 \\
-0.97 \\
1.28\end{array}$ & $\begin{array}{c}0.28 \\
-2.37 \\
3.02\end{array}$ & $\begin{array}{c}-0.85 \\
-1.80 \\
0.42\end{array}$ & $\begin{array}{c}1.12 \\
-0.14 \\
2.15\end{array}$ & $\begin{array}{l}0.783 \\
0.023 \\
0.005\end{array}$ \\
\hline $\begin{array}{l}\text { N Observasi } \\
\text { Adjusted } R^{2} \\
\mathrm{P}\end{array}$ & $\begin{array}{l}=42 \\
=28 \% \\
=0.003\end{array}$ & & & & \\
\hline
\end{tabular}

Sumber : Data Primer Februari 2014

Berdasarkan tabel 2 analisis multivariate regresi linier ganda 
menunjukkan hasil perhitungan Adjusted $R^{2} 0.28$ mengandung arti variabel metode role play dan gaya belajar secara bersamaan mampu menjelaskan $28 \%$ dari variasi keterampilan konseling, sedangkan sisanya dijelaskan oleh variabel yang tidak diteliti.

Hasil ketiga variabel yaitu metode role play dan gaya belajar, dengan keterampilan konseling secara statistik signifikan dengan nilai $\mathrm{p}=0.003$.

\section{Pembahasan}

1. Pengaruh penerapan metode role play terhadap keterampilan konseling Hasil analisis regresi linier ganda dalam penelitian ini bahwa setiap peningkatan 1 skor metode role play maka akan meningkat sebesar 6.86 skor keterampilan konseling $(\mathrm{b}=$ 6.86, CI $95 \%=64.35-92.31, \mathrm{p}=$ 0.009). Hal ini menunjukkan adanya pengaruh positif dan signifikan dari penerapan metode role play terhadap peningkatan keterampilan konseling. Sesuai dengan hipotesis yaitu mahasiswa dengan penerapan metode pembelajaran role play rata-rata memiliki keterampilan konseling lebih baik dibandingkan mahasiswa dengan penerapan metode pembelajaran konvensional.

Metode role play juga dapat memberikan kesenangan pada peserta didik. Menurut DePorter \& Hernacki (2013:43), masuklah ke dunia pebelajar, sambil kita antarkan dunia kita. Perasaan senang dapat menciptakan suasana belajar yang nyaman dan kondusif, serta merangsang peserta didik untuk ikut aktif selama proses pembelajaran berlangsung. Melalui keaktifan tersebut, tentunya akan meningkatkan perolehan hasil belajar peserta didik, dalam hal ini yaitu keterampilan konseling.

2. Pengaruh gaya belajar terhadap keterampilan konseling
Hasil analisis uji regresi linier ganda bahwa setiap peningkatan 1 skor gaya belajar visual maka akan meningkat sebesar 0.13 skor keterampilan konseling $(\mathrm{b}=0.13, \mathrm{CI}$ $95 \%=0.85-1.12, p=0.783)$. Hal ini menunjukkan ada pengaruh positif gaya belajar visual terhadap keterampilan konseling mahasiswa meskipun secara statistik tidak signifikan.

Untuk gaya belajar auditorial, bahwa setiap peningkatan 1 skor gaya belajar auditorial maka akan menurun sebesar 0.97 skor keterampilan konseling $(\mathrm{b}=-0.97$, CI 95\% $=(-1.80$ - (-0.14), $\mathrm{p}=0.023)$. Hal ini menunjukkan ada pengaruh negatif dan signifikan gaya belajar auditorial terhadap keterampilan konseling mahasiswa.

Untuk gaya belajar kinestetik, bahwa setiap peningkatan 1 skor gaya belajar kinestetik maka akan meningkat sebesar 1.28 skor keterampilan konseling $(\mathrm{b}=1.28, \mathrm{CI}$ $95 \%=0.42-2.15, p=0.005)$. Hal ini menunjukkan bahwa ada pengaruh positif dan signifikan gaya belajar kinestetik terhadap keterampilan konseling mahasiswa.

Hal ini sesuai dengan hipotesis penelitian yaitu mahasiswa yang mempunyai gaya belajar kinestetik rata-rata memiliki keterampilan konseling lebih baik dibandingkan mahasiswa dengan gaya belajar visual atau auditorial.

Hasil analisis yang menunjukkan perbedaan pengaruh gaya belajar terhadap keterampilan konseling, mungkin disebabkan karena masing-masing peserta didik memiliki gaya belajar yang berbeda. Pada gaya belajar auditorial terjadi penurunan keterampilan konseling, salah satunya disebabkan karena keterbatasan dari peneliti yaitu suara saat mengajar dinilai kurang keras oleh sebagian peserta didik. 
3. Pengaruh penerapan metode role play dan gaya belajar terhadap keterampilan konseling

Hasil analisis regresi linier ganda diperoleh nilai $\mathrm{p}=0.003$ yang menunjukkan bahwa terdapat pengaruh yang positif dan signifikan mengenai penerapan metode role play dan gaya belajar terhadap keterampilan konseling mahasiswa. Hasil perhitungan Adjusted $R^{2} 0.28$ mengandung arti variabel metode role play dan gaya belajar secara bersamaan mampu menjelaskan 28\% dari variasi keterampilan konseling, sedangkan sisanya dijelaskan oleh variabel yang tidak diteliti.

Proses pembelajaran dengan menggunakan metode role play dapat memberikan pengalaman langsung kepada peserta didik tentang bagaimana melakukan konseling terhadap permasalahan yang sedang dihadapi klien, serta membantu mencarikan solusi yang tepat.

Kualitas pembelajaran dalam hal ini metode mengajar, dan karakteristik peserta didik memiliki hubungan yang erat dalam suatu proses pembelajaran. Selain penerapan metode role play, gaya belajar peserta didik juga berpengaruh terhadap pencapaian tujuan pembelajaran.

\section{Keterbatasan Penelitian}

Keterbatasan dalam penelitian ini adalah sebagai berikut :

1. Populasi dan sampel yang digunakan hanya mahasiswi Prodi DIII Kebidanan FK. UNS berjumlah 42 orang.

2. Materi atau bahan ajar yang digunakan hanya mencakup indikator adaptasi dan perubahan psikologi pada masa kehamilan, sehingga kurang luas cakupan materinya.

Meskipun terdapat pengaruh positif dan signifikan variabel bebas terhadap variabel terikat, namun kontribusi yang dapat diberikan hanya sebesar $28 \%$ sehingga masih tersisa $72 \%$ dari faktor lain yang tidak diteliti dalam penelitian ini.

\section{PENUTUP}

Berdasarkan hasil penelitian dan analisis data dapat disimpulkan :

1. Ada pengaruh yang positif dan secara statistik signifikan pada penerapan metode role play terhadap keterampilan konseling $(\mathrm{b}=6.86, \mathrm{CI}$ $95 \%=64.35-92.31, \mathrm{p}=0.009$ ).

2. Ada pengaruh yang positif namun secara statistik tidak signifikan pada gaya belajar visual terhadap keterampilan konseling $(\mathrm{b}=0.13, \mathrm{CI}$ $95 \%=0.85-1.12, p=0.783$ )

3. Ada pengaruh negatif dan secara statistik signifikan pada gaya belajar auditorial terhadap keterampilan konseling $(\mathrm{b}=-0.97$, CI $95 \%=(-1.80$ $-(-0.14), p=0.023)$.

4. Ada pengaruh yang positif dan secara statistik signifikan pada gaya belajar kinestetik terhadap keterampilan konseling $(b=1.28$, CI 95\% $=0.42-$ $2.15, \mathrm{p}=0.005)$.

5. Ada pengaruh yang positif dan signifikan penerapan metode role play dan gaya belajar terhadap keterampilan konseling.

\section{Implikasi dan Saran}

Hasil penelitian membuktikan bahwa terdapat pengaruh yang positif dan signifikan antara penerapan metode role play dan gaya belajar terhadap keterampilan konseling mahasiswa program studi D III kebidanan fakultas kedokteran Universitas Sebelas Maret Surakarta. Maka perlu diperkuat adanya variasi metode mengajar kepada peserta didik dan dipertimbangkan kecenderungan gaya belajar yang dimiliki peserta didik agar pencapaian tujuan pembelajaran lebih optimal.

\section{DAFTAR PUSTAKA}

DePorter, B. \& Hernacky, M. 2013. Quantum learning. Bandung: Mizan Media Utama. 
Jannah, N. 2012. Buku Ajar Asuhan Kebidanan Kehamilan. Yogyakarta: CV. ANDI.

Majid, A. 2013. Strategi Pembelajaran. Bandung: PT. Remaja Rosdakarya.

Nasution, S. 2003. Berbagai Pendekatan Dalam Proses Belajar dan Mengajar. Jakarta: Bumi Aksara.

Sarwoko. 2009. Pengaruh Metode Role Play Terhadap Pencapaian Hasil Ujian Asuhan Kebidanan I Dengan Metode OSCA. Tesis Program Studi Kedokteran Keluarga Pascasarjana UNS. Surakarta.

Sofyan, W.S. 2007. Konseling Individual Teori dan Praktek. Bandung: Alfabeta.

Sulistyawati, A. 2009. Asuhan Kebidanan Pada Masa Kehamilan. Jakarta: Salemba Medika.

Uno, H.B. 2010. Model Pembelajaran: Menciptakan Proses Belajar Mengajar yang Kreatif dan Efektif. Jakarta: PT. Bumi Aksara.

Yamin. 2008. Desain Pembelajaran Berbasis Tingkat Satuan Pendidikan. Jakarta: Gaung Persada Press.

Yulifah, R. dan Yuswanto, T.J. 2009. Komunikasi dan Konseling Dalam Kebidanan. Jakarta: Salemba Medika.

Zaini, H., Munthe, B., \& Aryani, S. A. 2007. Strategi Pembelajaran Aktif. Yogyakarta: Pustaka Insan Madani. 